\title{
Anorectal malignant melanoma: A case report and treatment options
}

\section{Anorektal malign melanom: Bir olgu sunumu ve tedavi seçenekleri}

\author{
Hacı Hasan Abuoğlu ${ }^{1}$, Mehmet Gençtürk ${ }^{1}$, Mehmet Kamil Yıldız ${ }^{1}$, Onur İlhan ${ }^{1}$, Mehmet Gülmez ${ }^{1}$, \\ Kübra Kaytaz ${ }^{1}$, Selvinaz Özkara ${ }^{2}$
}

\begin{abstract}
Anorectal malignant melanoma (AMM) is a rare malignant disease with a poor prognosis. This disease is often confused with hemorrhoids. The most common site of malignant melanoma following skin and eye involvement is the anorectal region. This is the most commonly involved site in the gastrointestinal tract. We report the case of a 67-year-old patient with lower gastrointestinal hemorrhage for 4 months and hemorrhoid treatment for 2 months. The imaging revealed no distant metastasis but histopathologically, lymph node metastasis and invasion of surrounding tissues. Laparoscopic abdominoperineal resection (APR) was performed.
\end{abstract}

Key words: Anorectal diseases, malignant melanoma, surgery.

Öz

Anorektal melanom ( AMM) ender görülen, kötü prognozlu malign bir hastalıktır. Bu hastalık sıklıkla hemoroid ile karışmaktadır. Malign melanomanın deri ve göz tutulumundan sonra en sık görüldüğü bölge anorektal bölgedir. Bu bölge gastrointestinal sistemde en sık olarak tutulan bölgedir. Biz 67 yaşında, 4 aydır makattan kanama şikayetleri olan, 2 aydır da hemoroid tedavisi uygulanan hastayı sunduk. Yapılan görüntülemelerde hastanın uzak metastazının olmadığı ancak histopatolojik olarak lenf nodu metastazının ve çevre dokulara invazyonun olduğu izlendi. Hastaya laparoskopik abdominoperineal rezeksiyon ( APR ) yapildı.

Anahtar Kelimeler: Anorektal hastalıklar, malign melanom, cerrahi.
${ }^{1}$ University of Health Sciences, Haydarpaşa Training and Research Hospital, Department of General Suregry, Istanbul, Turkey.

${ }^{2}$ University of Health Sciences, Haydarpaşa Training and Research Hospital, Department of Pathology, Istanbul, Turkey.

\section{(iD)}

HHA: 0000-0002-2285-0685

HHA: $0000-0002-2285-0685$

MKY: $0000-0002-6172-0736$

Oİ: $0000-0001-5369-5510$

OI: $0000-0001-5369-5510$

MG: $0000-0002-3782-6039$

KK: 0000-0002-1898-3119

Informed Consent: The written consent was received from the patient who was presented in this study.

Hasta Onamı: Çalışmada sunulan hastadan yazılı onam alınmıştır.

Conflict of Interest: No conflict of interest was declared by the authors.

Çıkar Çatışması: Yazarlar çıkar çatışması bildirmemişlerdir.

Financial Disclosure: The authors declared that this case has received no financial support.

Finansal Destek: Yazarlar bu olgu için finansal destek almadıklarını beyan etmişlerdir.

Geliş Tarihi / Received: 07.11.2019

Kabul Tarihi / Accepted: 15.11.2019

Yayın Tarihi / Published: 01.12.2019

Sorumlu yazar / Corresponding author:

Mehmet Gençtürk

Adres/Address: Kurtköy Mah,. Ankara Cd., 390/3, 34912 Pendik/ İstanbul

e-mail:drgencturk@hotmail.com

Tel/Phone: +90 5079427492

Copyright (C) ACEM 


\section{Introduction}

Malignant melanoma is a rare disease, but it has usually a poor diagnosis because it is diagnosed late [1]. It can be mistaken for hemorrhoids. The incidence of malignant melanoma is $0.1-4.6 \%$ of all rectal malignancies [3]. The patient's complaints included rectal bleeding, palpable mass, breech pain, tenesmus and pruritis [5]. Its treatment is surgical, with extensive local excision or abdominoperineal resection [6]. In our 67-yearold woman, we performed abdominoperineal resection due to locally advancing of the tumor.

\section{Case report}

A 67-year-old female patient was treated with diagnosis of hemorrhoids in another hospital due to lower gastrointestinal hemorrhage, 4 months ago. The patient received medical treatment for 2 months. Physical examination revealed an irregular mass on the anorectal junction. Colonoscopy was planned. The colonoscopy showed a mass located at $3 . \mathrm{cm}$ from the anal canal and surrounding the anal canal (Figure 1). Histopathological examination revealed mucosal malignant melanoma (Figure 2). No other features were found in the other system examinations of our patient.

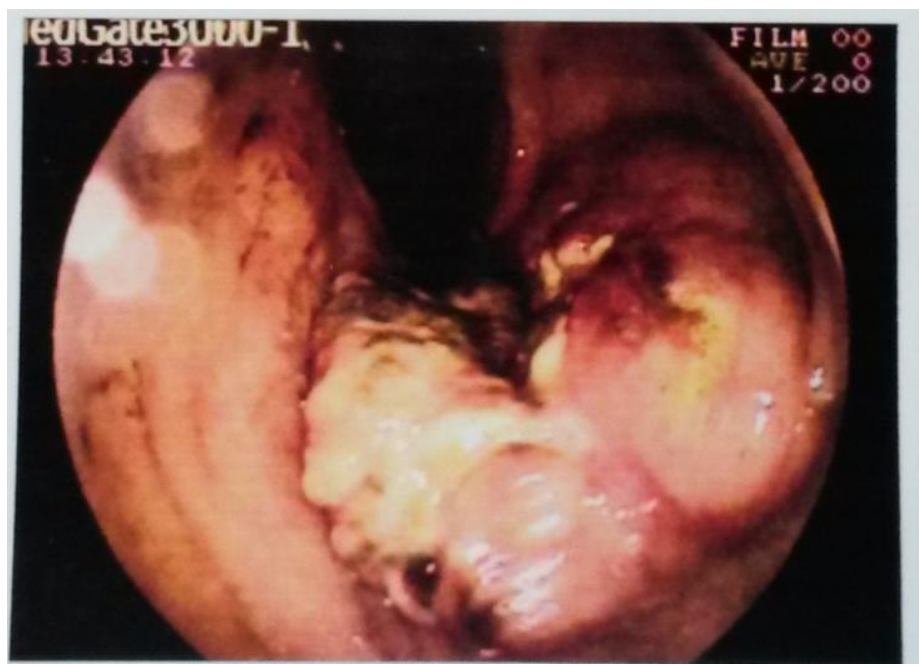

Figure 1: Colonoscopic image of anorectal malignant melanoma.

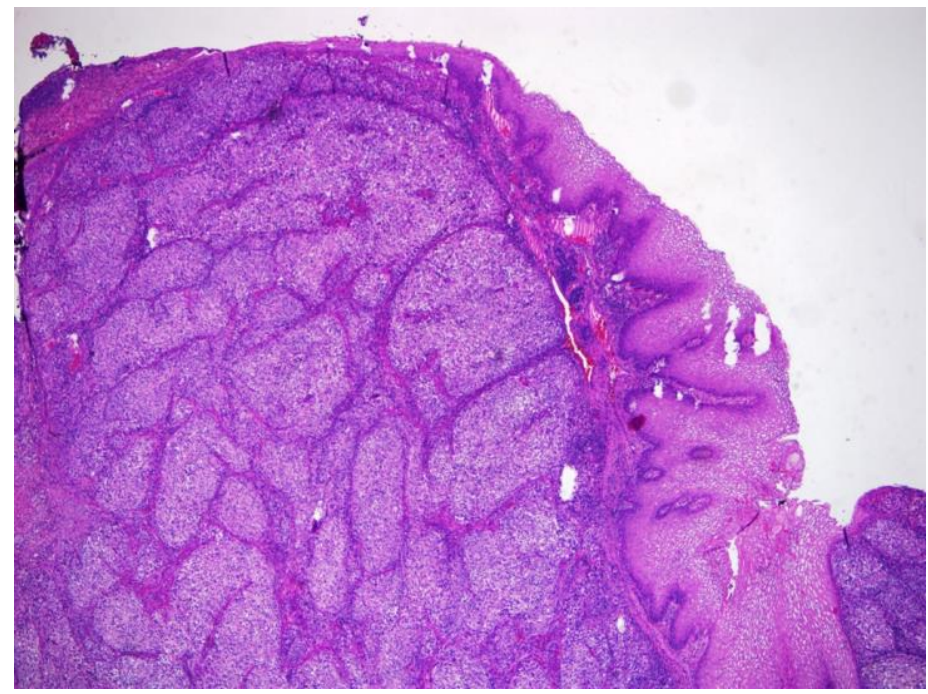

Figure 2: Histopathological imaging of anorectal malignant melanoma.

Abdominal computed tomography showed a mass lesion of $2.5 \mathrm{~cm}$ in diameter at the thickest site, and lymph nodes in the pararectal region, the largest of which was $3 * 1.5 \mathrm{~cm}$ in size. Increased attenuation suggesting infiltration was observed in perirectal fat plans (Figure 3 ). In addition, multiple diverticula were observed in the sigmoid colon and the descending colon (diverticulosis coli).

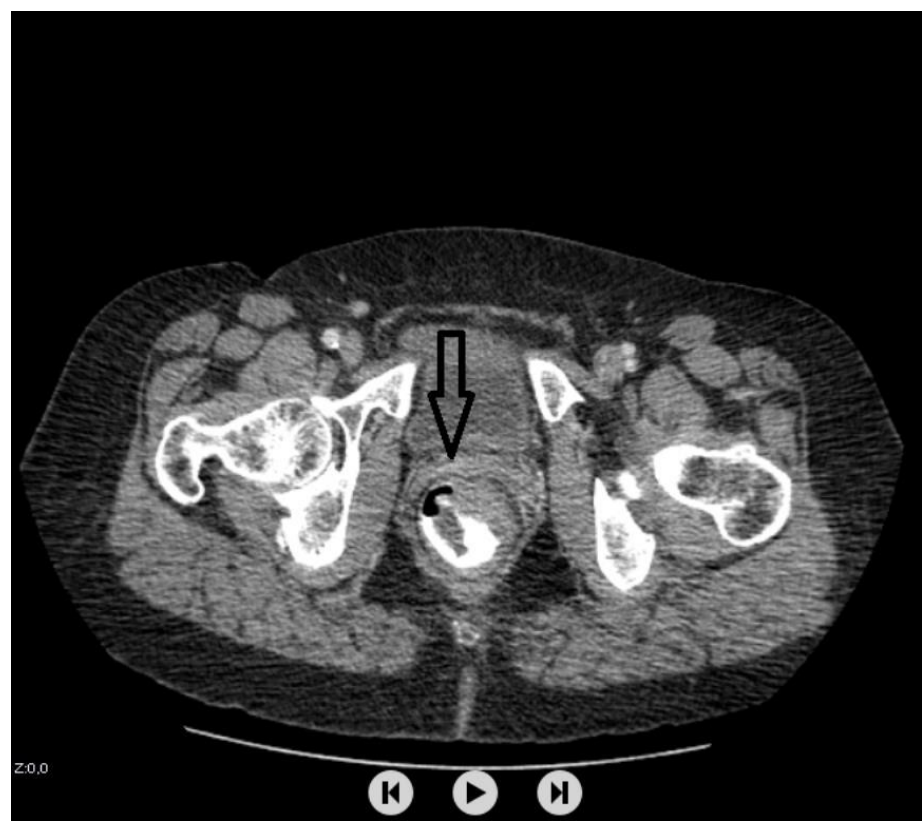

Figure 3: Computed tomography image of anorectal malignant melanoma.

Following preoperative evaluations, laparoscopic abdominoperinal resection was planned. Invasion of the mass into the posterior wall of the vagina was observed during surgery. The patient was consulted with gynecologist peroperatively. Total excision of the mass was completed including the vagina in the posterior wall. Histopathological examination revealed that the tumor was $5.5 \times 4 \times 1.2 \mathrm{~cm}$ in size, passed through the muscularis propria and showed direct invasion to the adipose tissue and surrounding structures. The patient had uneventful postoperative period and was discharged on the 7 th day.

Informed consent was obtained from the patient.

\section{Discussion}

Anorectal malignant melanoma is an extremely rare disease of neuroectodermal origin, which is aggressive and has a poor prognosis, and is usually fatal with late diagnosis [1]. Malignant melanoma of the anus and rectum was first reported by Moore in 1857 [2]. Rectal malignant melanomas constitute $0.2-3 \%$ of all malignant melanomas and $0.1-4.6 \%$ of rectal malignancies [3]. The most common symptom is rectal hemorrhage, so it is confused with hemorrhoidal disease and causes delays in diagnosis. Our patient also had medical treatment for a long time with the diagnosis of hemorrhoids. The most common symptoms of AMM include palpable mass, pain in the breech, changes in bowel habits, pruritis, tenesmus, and anorectal region $[1,5]$. In our patient, bleeding and severe pain in the breech area were prominent. The contribution of chemotherapy and radiotherapy is limited. Surgical treatment is still controversial even today [9]. In previous studies, radical resections such as abdominoperineal resection were accepted for treatment, whereas in recent studies there was no significant difference in survival and prognosis with wide local excision (WLE) technique [4]. Thibault et al. [5] recommended WLE 
with a negative surgical margin of at least $1 \mathrm{~cm}$ in treatment and recommended APR for palliative or non-WLE-only tumors for obstructing tumors. There is no consensus on the surgical margin in WLE and it should be noted that even a $1 \mathrm{~cm}$ negative surgical margin can lead to anal incontinence. Therefore, if negative surgical margin can be achieved without causing anal incontinence, WLE should be performed [6]. However, some studies have suggested that aggressive treatment with APR has a better survival rate, possibly associated with lymphadenectomy, that can control lymphatic spread (especially mesenteric lymph nodes) and that wider negative surgical margins and lower local recurrence rates can be achieved. [4, 8]. Yap et al. [1] reviewed 17 series published and reported that there was no statistically superiority between two techniques in all stages of the disease in their 5-year results. To sum up, treatment of anorectal malignant melanoma should be patient-specific [7].

In conclusion, in light of all these information, we preferred APR because of pathological appearance LAPs in the patient's pararectal region, infiltration in the perirectal fatty area and vaginal invasion. The closeness of the mass to the anal canal played a major role in this decision.

\section{References}

1. Yap LB, Neary P. A comparison of wide local excision with abdominoperineal resection in anorectal melanoma. Melanoma Res. 2004;14:147-50.

2. Meguerditchian AN, Meterissian SH, Dunn KB. Anorectal melanoma: diagnosis and treatment. Dis Colon Rectum. 2011;54:638-4.

3. Damodaran O, Morgan A, Mendelsohn G. Primary malignant melanoma in the anorectum: an uncommon cancer. $\mathrm{N} \mathrm{Z} \mathrm{Med} \mathrm{J.}$ 2008;121:66-8.

4. Yeh JJ, Shia J, Hwu WJ, et al.The role of abdominoperineal resection as surgical therapy for anorectal melanoma. Ann Surg. 2006; $244: 1012-17$

5. Thibault C, Sagar P, Nivatvongs S, Ilstrup DM, Wolff BG. Anorectal melanoma - an incurable disease. Dis Colon Rectum. 1997;40:661-8.

6. Malik A, Hull T, Floruta C. What is the best surgical treatment for anorectal melanoma? Int J Colorectal Dis. 2004;19:121-23.

7. Fazio VW, Church JM, Delaney CP. Current therapy in colon and rectal curgery. Second Edition. Philadelphia: Elsevier Mosby 2005;7981.

8. Pessaux P, Pocard M, Elias D, et al.Surgical management of primary anorectal melanoma. Br J Surg. 2004;91:1183-7. 